\title{
Risk of Infectious Complications in Patients Taking Glucocorticosteroids
}

\author{
Andreas E. Stuck, Christoph E. Minder, \\ and Felix J. Frey
}

From the Medizinische Poliklinik and Institut für Sozial-
und Präventivmedizin, University of Berne, Switzerland

\begin{abstract}
The association between corticosteroid therapy and subsequent infections was calculated by pooling data from 71 controlled clinical trials. The overall rate of infectious complications was $12.7 \%$ in the 2,111 patients randomly allocated to systemic corticosteroids and $8.0 \%$ in the 2,087 controls (relative risk [RR], 1.6; $95 \%$ confidence interval [CI], 1.3-1.9; $P<.001)$. The risk of infection was particularly high in patients with neurologic diseases (RR, 2.8; 95\% CI, 1.9-4.3; $P<.001$ ) and less pronounced in patients with intestinal (RR, $1.4 ; 95 \% \mathrm{CI}, 1.1-1.7 ; P=.02$ ), hepatic (RR, $1.4 ; 95 \% \mathrm{CI}, 0.9-2.3 ; P=.25$ ), and renal (RR $>1 ; P=.03$ ) diseases. The rate was not increased in patients given a daily dose of $<10 \mathrm{mg}$ or a cumulative dose of $<700 \mathrm{mg}$ of prednisone. With increasing doses the rate of occurrence of infectious complications increased in patients given corticosteroids as well as in patients given placebo, a finding suggesting that not only the corticosteroid but also the underlying disease state account for the steroid-associated infectious complications observed in clinical practice.
\end{abstract}

Corticosteroids in pharmacologic doses are commonly used to inhibit the immunologic network [1, 2]. As a consequence one might expect that the resistance to a wide variety of bacterial, viral, protozoal, and fungal agents is depressed, as was clearly demonstrated by numerous investigations in animals [3-5]. The effect of corticosteroids on the rate of infection was shown to depend upon many variables, including the dosage of the steroid and the resistance of the animal. These observations in animals were in accordance with the clinical impression of an increased rate of infections in patients treated with glucocorticoids.

Toxicologic studies in animals allow in many but not all instances for the prediction of potential adverse effects of a drug in humans and for the establishment of the underlying mechanism for such unwanted effects. However, such studies cannot provide a quantitative estimate of the rate of occurrence of a given adverse effect in humans. This might also be true for corticosteroids. For instance, a large number of the investigations dealing with the enhance-

Received for publication 14 December 1988 and in revised form 24 April 1989.

This work was supported by grant no. $3.877-0.85$ from the Swiss National Foundation for Scientific Research.

The authors are indebted to Dr. H. Murray for technical assistance and to Mrs. C. Weder for help in preparing the manuscript.

Please address correspondence to Dr. F. J. Frey, University of San Francisco, Transplant Service, Moffitt Hospital, Room 884, San Francisco, California 94143-0446. ment of the susceptibility to infectious agents were performed in so-called steroid-sensitive species, such as rodents [3-5], whereas humans belong to the group of steroid-resistant species [1]. The dosages of corticosteroids given to animals cannot be compared with those given to patients, because virtually all animal species investigated metabolize corticosteroids much faster and exhibit a different binding to plasma proteins than do humans [6-8]. Furthermore, some disease states, such as the nephrotic syndrome, Crohn's disease, alcoholic cirrhosis, structural bronchopulmonary diseases, rheumatic diseases, multiple sclerosis, cerebrovascular diseases, and cranial trauma, which have been or are being treated with corticosteroids, are considered to predispose to the development of infectious diseases [9-16]. Thus, the clinical evidence of an increased rate of infectious complications in patients given corticosteroids has to be considered with caution, and only the analysis of controlled trials may allow demonstration of a causal and quantitative relationship between therapy with corticosteroids and appearance of infections.

Therefore, we examined the association between corticosteroid therapy and subsequent infectious diseases by pooling data from controlled clinical trials in which patients were randomized to treatment with or without systemic corticosteroids. In order to establish whether the risk of infectious complications was dose dependent, we calculated the association between daily doses or cumulative doses of prednisone and the rate of infections. 


\section{Methods}

In the present investigation results of previous reports were combined and analyzed. This technique is designated meta-analysis $[17,18]$.

Selection criteria. A review of the English-language literature in which patients were assigned to receive systemic corticosteroids or nonsteroid therapy for at least 3 days was performed. For that purpose a MEDLINE computer search was supplemented by consultation with reviews, textbooks, and experts in the fields of hepatology, gastroenterology, pneumology, neurology, nephrology, and rheumatology and by review of references in all the trials found. The trials were analyzed according to a predetermined protocol.

Only controlled studies were included; studies in which adrenocorticotropic hormone was administered or in which systemic corticosteroid therapy was combined with cytostatic or other immunosuppressive agents were excluded. Trials in which patients were given antibacterial, antiviral, antifungal, or antiprotozoal agents were excluded, except when prophylactic isoniazid only was given. Studies were also excluded if the number of patients allocated to the treatment or placebo group was not indicated, if not enough information was given to estimate the dosage and duration of therapy, or if adverse effects were inadequately discussed (see below).

With regard to crossover studies, only data from the first arm of the study were included. No attempt was made to supplement data through personal communication. Eventually, 71 trials were included [1990] for the final meta-analysis. A list of 58 relevant publications excluded from the final analysis can be obtained from the authors.

Complications. For analysis of nonlethal infectious complications, trials with inadequate discussion of adverse effects (i.e., not mentioned at all, not clearly enumerated for each treatment group, or too vaguely described) were excluded. If complications of therapy were described but an infection was not specifically mentioned, the paper was included on the assumption that no infectious complication occurred. For the analysis of lethal infectious complications, only trials specifying the causes of death were included. An infection was considered lethal if it was the main cause and not just a contributing cause of death. If all patients survived the trial, it was evident that no lethal infectious complication occurred.

Dosage and duration of therapy. Duration was measured as the number of days; if it varied among the patients in any study, the median duration was estimated. Steroid dosage was expressed in prednisone-equivalent milligrams [90] and evaluated in two ways - either as a cumulative dose or as a mean daily dose (cumulative dose divided by duration). If a trial included children, only adult dosage was considered for analysis. Thus, the conclusions derived from the present meta-analysis are only relevant for adult patients.

Statistical procedures. Statistical analysis for comparison of the number of infectious complications per 100 patients between patients with and without steroid therapy was performed according to three different methods: simple $\chi^{2}$ analysis of the pooled data, the Mantel-Haenszel technique of pooling individual $\chi^{2}$ values (with each study as a stratum), and the Mantel-Haenszel technique using Yates's correction for $\chi^{2}$ values with small numbers [91]. If the $P$ values derived by all three methods were on the same side of .05 , only the highest is reported; if they were on both sides of .05 , a range is given. The $95 \%$ confidence interval (CI) of the relative risk (RR) was calculated with use of the method described by Katz et al. [92].

In the analysis of the effect of steroid therapy adjusted for duration, the incidence (rate per 1,000 patients per 21 days) was calculated. The period of 21 days was chosen because it was the median duration of therapy in the 71 trials analyzed. The $95 \% \mathrm{CI}$ and the $P$ values were calculated by assuming a Poisson distribution of new cases, with the mean proportional to the number of patient-days observed [93]. For analysis of pooled trials with $\geqslant 20$ infectious complications, an asymptotic $95 \%$ CI was calculated, while for analysis of pooled trials with $<20$ infectious complications the exact $95 \% \mathrm{CI}$ was used. In addition, Wilcoxon's rank sum test was used for comparison of subgroups of patients (as indicated in Results).

The analysis of the trials revealed that patients with a cumulative dose of $<500 \mathrm{mg}$ of prednisone or a mean dose of $<10 \mathrm{mg}$ of prednisone daily had no more infectious complications than did controls. For these subgroups of patients, a Type II error analysis was performed, again assuming a Poisson distribution [93].

\section{Results}

In all, 4,198 patients (1,969 male, 1,415 female, 814 unknown) were analyzed. It was not possible to ana- 
lyze the infectious complications according to age and/or sex because not enough information was given in the reports of the trials. In order to estimate the age of all the patients investigated, the median value (range) of the median or mean age given in 46 trials was used: 46.1 years (25.8-74.5 years). The underlying diseases were: pulmonary diseases (364 patients), liver diseases (979), neurologic diseases $(1,223)$, nephrotic syndrome (197), rheumatic diseases (167), inflammatory bowel diseases (807), and other diseases (461).

Among the 71 trials, 23 papers reported infectious complications. In $16(70 \%)$ of these 23 , the steroid group had more lethal and nonlethal infections than the controls, while in five trials $(22 \%)$ the controls had more infections and in two $(9 \%)$ an identical number of infections were reported in both groups. The overall rate of lethal and nonlethal infectious complications was $12.7 \%$ in the steroid-treated patients and $8.0 \%$ in the controls $(P<.001)$ (table 1$)$. Both lethal and nonlethal complications were increased in patients given corticosteroids, the relative risk being $2.6(95 \% \mathrm{CI}, 1.2-5.3)$ and $1.6(1.3-1.9)$, respectively.
When separate analyses were performed for doubleblind studies, studies using oral steroids, and studies using parenteral steroids, similar increased relative risks were found (table 1). When the 10 trials including both adults and children were excluded from analysis, similar statistically significant differences of infectious complications between the patients with and without steroids were observed (results not shown). In three investigations more than one infection per patient was possible, while in the remaining 68 trials, not more than one infection per patient was reported. When only these 68 trials were analyzed, similar differences were found between patients given steroids and controls (results not shown).

The relative risk in steroid-treated patients with a mean dose of $<20 \mathrm{mg} / \mathrm{d}$ was 1.3 (95\% CI, 1.0-1.6), as compared with 2.1 (1.3-3.6) in patients treated with a mean dose of $20-40 \mathrm{mg} / \mathrm{d}$. When patients were given a mean daily dose $>\mathbf{4 0} \mathrm{mg}$, no further increase in the relative risk was observed (table 2). This may be best explained by the shorter median duration of therapy in the patients given $>40 \mathrm{mg}$ of prednisone/d than in those given $20-40 \mathrm{mg} / \mathrm{d}$ (median 12 days, range 3-180 days vs. median 28 days, range 6-180

Table 1. Analysis of lethal and nonlethal infectious complications in steroid-treated and control patients.

\begin{tabular}{|c|c|c|c|c|c|c|c|c|c|}
\hline \multirow{3}{*}{$\begin{array}{l}\text { Category } \\
\text { of trial } \\
\text { (no.) }\end{array}$} & \multicolumn{2}{|c|}{$\begin{array}{l}\text { No. of } \\
\text { patients }\end{array}$} & \multicolumn{2}{|c|}{$\begin{array}{c}\text { No. of } \\
\text { infectious } \\
\text { complications/ } \\
100 \text { patients }\end{array}$} & \multirow{3}{*}{$\begin{array}{c}P \\
\text { value }\end{array}$} & \multirow{3}{*}{$\begin{array}{l}\text { Relative risk } \\
(95 \% \mathrm{CI})\end{array}$} & \multirow{2}{*}{\multicolumn{2}{|c|}{ Incidence ${ }^{\dagger}(95 \% \mathrm{CI})$}} & \multirow{3}{*}{$\begin{array}{c}P \\
\text { value }\end{array}$} \\
\hline & \multirow{2}{*}{$\begin{array}{l}\text { Steroid- } \\
\text { treated }\end{array}$} & \multirow[b]{2}{*}{ Control } & \multirow{2}{*}{\multicolumn{2}{|c|}{$\begin{array}{l}\text { Steroid- } \\
\text { treated Control }\end{array}$}} & & & & & \\
\hline & & & & & & & Steroid-treated & Control & \\
\hline \multicolumn{10}{|l|}{ Total } \\
\hline All (71) & 2,111 & 2,087 & 12.7 & 8.0 & $<.001$ & $1.6(1.3-1.9)$ & $11.9(10.4-13.3)$ & $7.5(6.4-8.7)$ & $<.001$ \\
\hline Lethal (71) & 2,111 & 2,087 & 1.2 & 0.5 & .02 & $2.6(1.2-5.3)$ & $1.1(0.7-1.6)$ & $0.5(0.2-0.8)$ & .009 \\
\hline Nonlethal (56) & 1,665 & 1,669 & 14.7 & 9.4 & $<.001$ & $1.6(1.3-1.9)$ & $18.3(16.0-20.6)$ & $12.1(10.2-13.9)$ & $<.001$ \\
\hline \multicolumn{10}{|l|}{ Double-blind } \\
\hline All (56) & 1,551 & 1,507 & 15.7 & 10.1 & $<.001$ & $1.5(1.3-1.9)$ & $26.1(22.8-29.3)$ & $18.0(15.2-20.9)$ & $<.001$ \\
\hline Lethal (56) & 1,551 & 1,507 & 0.9 & 0.2 & .03 & $4.5(1.3-15.8)$ & $1.5(0.8-2.3)$ & $0.4(0.1-1.0)$ & .01 \\
\hline Nonlethal (42) & 1,405 & 1,433 & 16.4 & 10.5 & $<.001$ & $1.6(1.3-1.9)$ & $26.3(22.9-29.7)$ & $18.9(15.9-21.9)$ & .001 \\
\hline \multicolumn{10}{|l|}{ Oral steroids* } \\
\hline All (52) & 1,550 & 1,574 & 10.5 & 7.4 & .003 & $1.4(1.1-1.9)$ & $7.3(6.1-8.4)$ & $5.4(4.4-6.4)$ & .01 \\
\hline Lethal (52) & 1,550 & 1,574 & 0.6 & 0.1 & $.02-.19$ & $5.1(1.1-23.1)$ & $0.5(0.2-0.8)$ & $0.1(0.01-0.3)$ & .02 \\
\hline Nonlethal (40) & 1,131 & 1,184 & 13.5 & 9.8 & .005 & $1.4(1.1-1.9)$ & $11.8(9.9-13.6)$ & $9.1(7.5-10.8)$ & .007 \\
\hline \multicolumn{10}{|c|}{ Parenteral steroids* } \\
\hline All (13) & 459 & 397 & 21.8 & 9.3 & $<.001$ & $2.3(1.6-3.3)$ & $484.1(389.2-579.0)$ & $211.6(143.4-279.8)$ & $<.001$ \\
\hline Lethal (13) & 459 & 397 & 3.1 & 1.5 & .15 & $2.0(0.8-5.2)$ & $67.8(37.0-103.3)$ & $34.3(12.6-74.3)$ & .14 \\
\hline Nonlethal (12) & 432 & 369 & 19.9 & 8.4 & .004 & $2.4(1.6-3.5)$ & $424.2(334.6-513.9)$ & $181.4(117.6-245.3)$ & $<.001$ \\
\hline
\end{tabular}

* Six trials could not be included in these two (oral or parenteral) categories because combined oral and parenteral therapy was administered in these trials.

$\dagger$ Number of infectious complications/(1,000 patients $\cdot 21 \mathrm{~d})$. 
Table 2. Lethal and nonlethal infectious complications, according to mean daily steroid dose, median duration of therapy, and total cumulative steroid dose.

\begin{tabular}{|c|c|c|c|c|c|c|c|c|c|}
\hline \multirow{3}{*}{$\begin{array}{l}\text { Category } \\
\text { of trial } \\
\text { (no.) }\end{array}$} & \multicolumn{2}{|c|}{$\begin{array}{l}\text { No. of } \\
\text { patients }\end{array}$} & \multicolumn{2}{|c|}{$\begin{array}{l}\text { Infectious } \\
\text { complications/ } \\
100 \text { patients }\end{array}$} & \multirow{3}{*}{$\begin{array}{c}P \\
\text { value }\end{array}$} & \multirow{3}{*}{$\begin{array}{c}\text { Relative risk } \\
(95 \% \mathrm{CI})\end{array}$} & \multirow{2}{*}{\multicolumn{2}{|c|}{ Incidence* $(95 \% \mathrm{CI})$}} & \multirow{3}{*}{$\begin{array}{c}P \\
\text { value }\end{array}$} \\
\hline & \multirow{2}{*}{$\begin{array}{l}\text { Steroid- } \\
\text { treated }\end{array}$} & \multirow{2}{*}{ Control } & \multirow{2}{*}{\multicolumn{2}{|c|}{$\begin{array}{l}\text { Steroid- } \\
\text { treated Control }\end{array}$}} & & & & & \\
\hline & & & & & & & Steroid-treated & Control & \\
\hline \multicolumn{10}{|l|}{$\begin{array}{l}\text { Daily steroid dose } \\
\text { (mg) }\end{array}$} \\
\hline$<20(13)$ & 657 & 689 & 17.8 & 14.2 & $.03-.07$ & $1.3(1.0-1.6)$ & $5.8(4.8-6.9)$ & $5.0(4.0-6.0)$ & .27 \\
\hline $20-40(31)$ & 652 & 621 & 6.8 & 3.2 & .003 & $2.1(1.3-3.6)$ & $22.6(16.0-29.2)$ & $10.6(6.0-15.3)$ & .004 \\
\hline$>40(27)$ & 802 & 777 & 13.5 & 6.3 & .005 & $2.1(1.6-2.9)$ & $150.7(122.3-179.2)$ & $66.5(47.9-85.1)$ & $<.001$ \\
\hline \multicolumn{10}{|l|}{$\begin{array}{l}\text { Duration of } \\
\text { therapy (d) }\end{array}$} \\
\hline$<30(43)$ & 1,062 & 998 & 10.5 & 4.7 & .001 & $2.3(1.7-3.4)$ & $177.0(144.4-209.6)$ & $81.9(58.5-105.3)$ & $<.001$ \\
\hline$\geqslant 30(28)$ & 1,049 & 1,089 & 15.0 & 11.0 & .007 & $1.4(1.1-2.3)$ & $7.1(6.0-8.2)$ & $5.6(4.6-6.5)$ & .04 \\
\hline \multicolumn{10}{|l|}{$\begin{array}{l}\text { Cumulative steroid } \\
\text { dose (mg) }\end{array}$} \\
\hline$<500(15)$ & 264 & 247 & 0.8 & 0.8 & .95 & $0.9(0.1-6.6)$ & $12.2(1.5-44.0)$ & $13.0(1.6-46.7)$ & .95 \\
\hline $500-999(19)$ & 422 & 432 & 5.3 & 2.7 & $.05-.27$ & $2.0(1.0-3.9)$ & $49.1(29.0-69.2)$ & $25.3(11.6-39.7)$ & .06 \\
\hline $1,000-1,999(13)$ & 306 & 266 & 14.7 & 5.6 & .02 & $2.6(1.5-4.6)$ & $83.9(59.4-108.4)$ & $29.2(16.4-44.0)$ & $<.001$ \\
\hline$\geqslant 2,000(24)$ & 1,119 & 1,142 & 17.9 & 12.1 & $<.001$ & $1.5(1.2-1.8)$ & $9.3(8.0-10.5)$ & $6.6(5.5-7.7)$ & .002 \\
\hline
\end{tabular}

* Number of infectious complications/(1,000 patients $\cdot 21 \mathrm{~d})$.

days; $P<.01$, Wilcoxon's rank sum test). Similarly the lower relative risk in patients treated for $\geqslant 30$ days, compared with that in patients treated for $<30$ days (table 2), can be explained by the lower mean daily dose in the patients treated for $\geqslant 30$ days (median $26.7 \mathrm{mg}$, range $5-50 \mathrm{mg}$ vs. median $41 \mathrm{mg}$, range 5-1,926 mg; $P<.001$, Wilcoxon's rank sum test).

One might anticipate that both the daily dose of prednisone and the duration of therapy determine the incidence of infectious complications. The combined impact of these two determinants on the incidence of infectious complications is illustrated in figure 1. From that figure it can be seen that in none of the 21 trials with a cumulative dose of $<700 \mathrm{mg}$ of prednisone was the number of infectious complications reported in steroid-treated patients higher than in controls. A Type II error analysis revealed that an increase in the frequency of infectious complications from $0.8 \%$ (table 2) to $>2.4 \%$ in the patients on a cumulative corticosteroid dose of $<500$ $\mathrm{mg}$ can be rejected at the 0.05 confidence level. In none of the five trials with a mean daily dose of $<10$ $\mathrm{mg}$ of prednisone were more infectious complications reported in the patients given steroids than in the controls (figure 1). An incidence of $>1.1$ infectious complications $/[1,000$ patients $\cdot 21 \mathrm{~d}]$, or $>3.3$ infectious complications $/ 100$ patients, can be rejected for the patients given $<10 \mathrm{mg}$ prednisone/ $\mathrm{d}$ at the 0.05 confidence level.

The incidence of infectious complications in patients with different underlying diseases is shown in table 3. In patients with pulmonary and rheumatic diseases, no infections were observed in steroidtreated and in control patients. In the other five disease states, the frequency of infectious complications in steroid-treated patients ranged from 1.8 to 33.9 / 100 patients and from 0.0 to $24.9 / 100$ patients in the control subjects (frequencies for the individual categories of trials are not shown in table 3 ). The resulting relative risk was $>1$ in each of these five strata, being highest in patients with neurologic diseases (RR, 2.8; 95\% Cl, 1.9-4.3; $P<.001$ ), and less pronounced in patients with intestinal (RR, 1.4; $95 \%$ CI, 1.1-1.7; $P=.02$ ), hepatic (RR, $1.4 ; 95 \% \mathrm{CI}$, $0.9-2.3 ; P=.25$ ), renal (RR, $>1 ; 95 \%$ CI not quantifiable because of zero in the denominator; $P=.03$ ), and other diseases (RR, 1.1; 95\% CI, 0.3-4.3; $P=$ .95) ( $R R$ derived from frequencies not shown in table 3).

\section{Discussion}

The main purpose of a controlled clinical trial of corticosteroids is to establish the efficacy of such 


\section{NCDENCE OF NFECTIONS IN 71 CONTROLLED TRIALS WITH PREDNISONE}

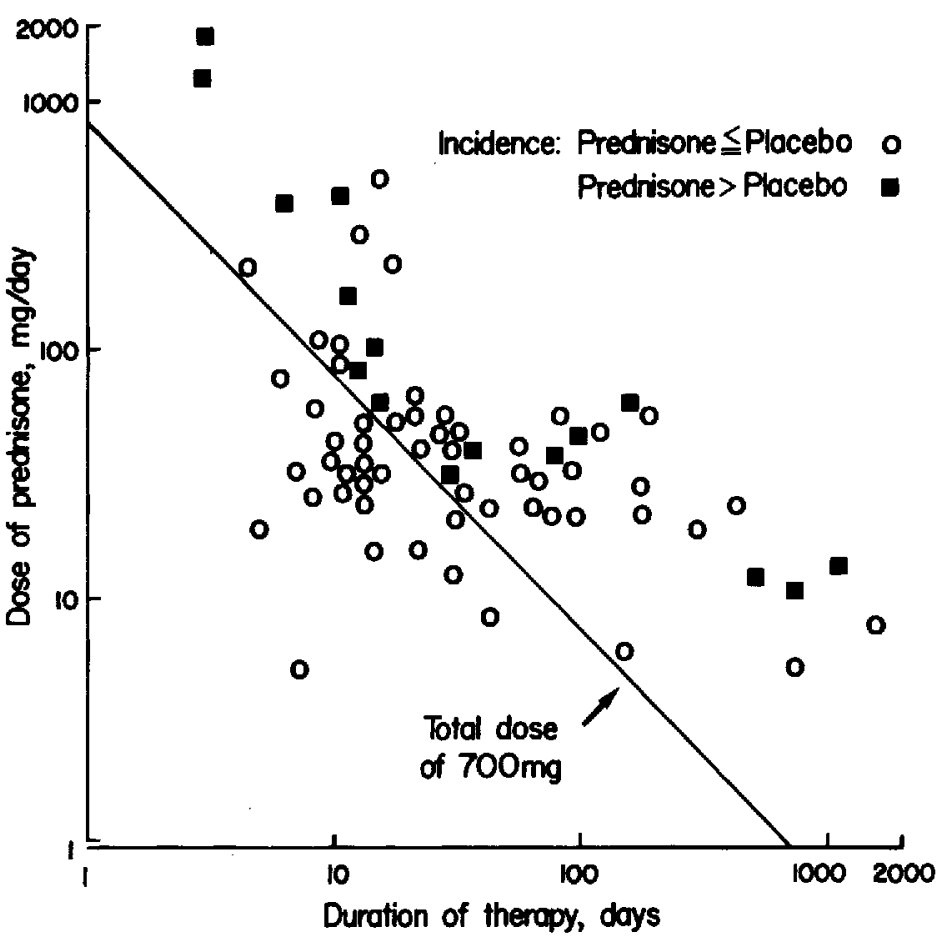

Figure 1. Double-logarithmic plot of the mean daily dose of prednisone vs. the median duration of therapy in 71 controlled trials. Each symbol represents one trial. The position of a symbol reflects the mean daily dose of prednisone ( $y$ axis) and the median duration of therapy prescribed ( $x$ axis) in a given trial. The closed squares ( $\square$ ) represent trials with a higher numerical incidence of infectious complications in the group of patients treated with prednisone than in the group of controls, whereas the open circles $(O)$ represent trials without a higher incidence of infectious complications in patients given prednisone than in controls. The product of the duration of therapy times the daily dose is the cumulative dose of prednisone prescribed. The cumulative dose of $700 \mathrm{mg}$ of prednisone is given by the oblique line. Note that all trials with a higher incidence of infections in patients given prednisone than in those given placebo are located above the isodose line of $700 \mathrm{mg}$, an indication that, independent of the dosage regimen, patients with a cumulative dose of $<700 \mathrm{mg}$ had no increased risk of infectious complications. therapy in a disease state. Special emphasis is therefore given to the assessment of the final therapeutic objective while the assessment of the adverse effects may be neglected. Thus, the report of the multiple adverse effects is usually much less detailed than the report of the impact of the corticosteroid on the underlying disease state. As a consequence, publications dealing with corticosteroid therapy might be qualitatively or quantitatively deficient with regard to the report of infectious complications. The qualitative deficiency in reporting infectious complications is clearly demonstrated by the fact that in $<8 \%$ of the infections reported was the nature of the infectious disease, i.e., bacterial, viral, fungal, or protozoal, indicated.

On the basis of the data given in the publications of the controlled trials, it cannot be established whether all or only a fraction of the infectious com-

Table 3. Number of patients, daily prednisone dose, and duration of therapy in steroid-treated and control patients, according to the underlying disease state.

\begin{tabular}{|c|c|c|c|c|c|c|c|}
\hline \multirow{2}{*}{$\begin{array}{l}\text { Category of } \\
\text { trials (no.) }\end{array}$} & \multicolumn{2}{|c|}{ No. of patients } & \multirow{2}{*}{$\begin{array}{c}\text { Median daily } \\
\text { steroid dose } \\
\text { in } \mathrm{mg} \\
\text { (range) }\end{array}$} & \multirow{2}{*}{$\begin{array}{c}\text { Median duration } \\
\text { of therapy } \\
\text { in days } \\
\text { (range) }\end{array}$} & \multicolumn{2}{|c|}{ Incidence* $(95 \% \mathrm{CI})$} & \multirow{2}{*}{$\begin{array}{c}P \\
\text { value } \\
\end{array}$} \\
\hline & treated & Control & & & Steroid-treated & Control & \\
\hline Intestinal (4) & 386 & 421 & $18(12-33)$ & $195(80-512)$ & $19.4(16.1-22.7)$ & $16.7(13.5-19.9)$ & .25 \\
\hline Hepatic (19) & 494 & 485 & $40(7-1,250)$ & $28(9-1,600)$ & $3.9(2.7-5.0)$ & $2.6(1.7-3.5)$ & .09 \\
\hline Neurologic (18) & 633 & 590 & $90(20-426)$ & $12(6-180)$ & $166.4(131.0-201.7)$ & $55.1(34.7-75.5)$ & $<.001$ \\
\hline Pulmonary (14) & 191 & 173 & $30(13-40)$ & $14(7-180)$ & $0.0(0.0-7.8)$ & $0.0(0.0-8.6)$ & .99 \\
\hline Renal (2) & 95 & 102 & $26(11-41)$ & $421(112-730)$ & $2.6(0.8-4.6)$ & $0.0(0.0-1.5)$ & .01 \\
\hline Rheumatic (5) & 89 & 78 & $8(5-22)$ & $42(14-730)$ & $0.0(0.0-3.4)$ & $0.0(0.0-4.9)$ & .99 \\
\hline Other (9) & 223 & 238 & $36(18-1,926)$ & $20(3-84)$ & $12.1(4.5-30.2)$ & $12.9(4.0-32.4)$ & .95 \\
\hline
\end{tabular}

* Number of infectious complications/(1,000 patients $\cdot 21 \mathrm{~d})$. 
plications were reported. It is conceivable that only severe infectious complications and/or well-defined infections (for instance, pneumonia or herpes zoster) were reported, and minor and/or not well defined entities such as urinary tract infection or flulike syndromes were omitted. Thus, the quantitative results of the incidence of infectious complications derived from the present meta-analysis might indeed underestimate the true number of infections. Nevertheless, the differences in the incidence of infectious complications between patients on corticosteroids and controls are likely to be true, because underreporting can be expected in both groups of patients; overreporting of (expected) infectious complications in patients on corticosteroids can be excluded, because similar differences were observed when only the double-blind studies were analyzed (table 1 ).

Overall, $13 \%$ and $7 \%$ of the patients with and without corticosteroid therapy, respectively, had infectious complications. In most trials the patients were withdrawn from the study when the first infectious complication appeared. Since the point when the individual infectious complication occurred was often not indicated, it was not possible to correct the incidence of infectious complications according to the true duration of therapy. Therefore, the total duration of the study for the patients on placebo was probably slightly longer than for the group of patients given corticosteroids and thus increased the likelihood of infectious complications in control subjects. Furthermore, the true incidence of infectious complications in clinical practice (not under clinical study conditions) might be higher than in the present analysis because therapy is not usually withheld when the first infectious complication occurs.

The rate of infectious complications $/[1,000$ patients $\cdot 21 \mathrm{~d}$ ] increased from 22.6 in patients given 20-40 mg of prednisone/d to 150.7 in patients given $>40 \mathrm{mg}$ of prednisone/ $\mathrm{d}$ (table 2 ). This dose dependency of the incidence of infectious complications was not paralleled by an increase in the relative risk, since the incidence of infections rose with increasing dosage in the corresponding control groups as well (table 2). This indicates that the underlying disease state, which dictates the dosage regimen of steroids, largely accounts for the variable and dosedependent incidence of infectious complications observed in clinical practice.

Both the relative risk and the rate of infectious complications/ $[1,000$ patients $21 \mathrm{~d}]$ increased with increasing cumulative steroid dose up to $1,999 \mathrm{mg}$ and declined when a cumulative dose of $\geqslant 2,000 \mathrm{mg}$ of prednisone was given (table 2). The decline of the relative risk of infectious complications at the highest cumulative steroid dose may be attributable to investigations in which a low dose of prednisone was prescribed for a very long period. Indeed, a mean daily steroid dose of $<10 \mathrm{mg}$ of prednisone for a long period was not associated with an increased relative risk of infectious complications (figure 1).

The incidence of infectious complications in patients treated with parenteral steroid was $484 /[1,000$ patients $\cdot 21 \mathrm{~d}]$. This rate has to be interpreted with caution because the median duration of the trials with parenteral treatment was $<21$ days. The reason for the much higher incidence of infectious complications in patients given parenteral compared with patients given oral steroids cannot be attributed to a low systemic availability of oral steroids [94] but rather to the high incidence of infectious complications in the corresponding (parenteral) controls and to the higher dose of corticosteroids prescribed in parenteral as opposed to oral form (results not shown).

The underlying disease state was a determinant of the incidence of infectious complications observed in control patients. Control patients with neurologic diseases had the highest incidence of infectious complications among the seven categories of trials (table 3). These subjects were the controls of the patients treated for a relatively short period with the highest daily dose of prednisone (table 3 ), a fact suggesting that the entire neurologic patient population was in a severe disease state that required high steroid doses and made the subjects highly susceptible to infectious complications. The absence of infectious complications in the control subjects of the prednisone-treated patients with pulmonary and renal diseases is probably best explained by the short duration of therapy and/or low dose of prednisone, a situation indicating a less-severe disease state than in patients with neurologic diseases (table 3). Alternatively, it is conceivable that neurologic diseases predispose patients to infectious complications more frequently than the other diseases and/or that the infectious complications were reported more accurately by the neurologists than by the physicians conducting the other trials.

While the comparison of the incidence of infectious complications between control subjects with different underlying diseases is biased by the investigators who performed the studies, the comparison of the incidence between patients with and without 
steroid therapy is not. When compared with the mean relative risk of infectious complications derived from all the studies analyzed (table 1), the risk in patients with intestinal, hepatic, renal, or other diseases (table 3 ) was roughly what was expected, while the risk in patients with neurologic diseases was abnormally high and in patients with pulmonary or rheumatic diseases, abnormally low. The threefold increase of the incidence of infectious complications in steroidtreated patients with neurologic diseases, compared with that in control patients with neurologic diseases (table 3), strongly suggests that this patient population exhibits an unusually high sensitivity to the induction of infectious complications by corticosteroids. However, since patients with neurologic diseases were given higher doses of prednisone than patients with other diseases (table 3), it cannot be decided whether the higher risk of complications was attributable to the higher steroid dosage or to a higher sensitivity to the adverse effects of steroids as a result of the underlying disease. Similarly, the absence of an increased risk of infectious complications in patients with pulmonary or rheumatic diseases might be attributable to the low dosage of prednisone, to the short duration of therapy, or to the underlying disease state (table 3 ).

The present analysis revealed no increased risk of infectious complications in patients given a daily dose of $<10 \mathrm{mg}$ or a cumulative dose of $<700 \mathrm{mg}$ of prednisone. It would be erroneous to conclude that the prescription of lower doses of prednisone is absolutely safe for the following reasons. As is true for all patients participating in controlled clinical trials, the patients considered in the present metaanalysis are only partly representative of the patients treated in clinical practice. For instance, in controlled clinical trials most patients have a single well-defined disease, whereas in clinical practice the situation is often more complicated. In clinical practice one might have to initiate therapy with prednisone in patients who are already suffering from an infection or who are immunocompromised, conditions that might have precluded the participation in a controlled trial with prednisone. Furthermore, certain states, such as renal failure, hepatic disease, old age, or concomitant drug therapy (e.g., ketoconazole or oral contraceptive steroids), decrease the metabolism of prednisolone [95-100] and therefore might increase the likelihood of infections even at doses below the threshold doses for increased risk of infections found in the controlled trials. Conversely, patients with an enhanced catabolism of the steroid because of induced microsomal liver enzymes by xenobiotics (mainly phenytoin, barbiturates, or rifampin) or because of hyperthyroidism exhibit less immunosuppressive effect - and as a corollary less infectious risk - from the same dose of prednisone than do patients with a normal steroid metabolism [101-103]. Thus, knowledge of the dose of prednisone below which no increased risk of infections was found in controlled trials is only meaningful information when it is used in conjunction with knowledge of the pretherapy susceptibility to infection and the metabolism of the steroid.

This meta-analysis demonstrates within the limits of the methods employed [16] that glucocorticoids increase the risk of lethal and nonlethal infectious complications, a result in accordance with uncontrolled observations in clinical practice. In addition, the analysis of the controlled trials reveals two new concepts that are of practical relevance: (1) the risk of prednisone therapy-associated infectious complications is dose dependent, with no increased risk in patients given a daily dose of $<10 \mathrm{mg}$ or a cumulative dose of $<700 \mathrm{mg}$ of prednisone; and (2) the risk of prednisone therapy-associated infectious complications is particularly high in patients with neurologic diseases and less pronounced in patients with intestinal, hepatic, or renal diseases, an indication that the susceptibility to infection is due not only to the prednisone therapy but also to the type and severity of the underlying disease.

\section{References}

1. Cupps TR, Fauci AS. Corticosteroid-mediated immunoregulation in man. Immunol Rev 1982;65:133-55

2. Frey BM, Walker C, Frey FJ, de Weck AL. Pharmacokinetics and pharmacodynamics of three different prednisolone prodrugs: effect on circulating lymphocyte subsets and function. J Immunol 1984;133:2479-87

3. Kass EH, Finland M. Adrenocortical hormones in infection and immunity. Ann Rev Microbiol 1953;7:361-88

4. Kass EH, Finland M. corticosteroids and infections. Adv Intern Med 1958;9:45-80

5. Kass EH. Hormones and host resistance to infection. Bacteriological Reviews 1960;24:177-85

6. Rocci ML Jr, Johnson NF, Jusko WJ: Serum protein binding of prednisolone in four species. J Pharm Sci 1980; 69:977-80

7. Frey FJ, Frey BM, Greither A, Benet LZ. Prednisolone clearance at steady state in dogs. J Pharmacol Exp Ther 1980;215:287-91

8. Frey BM, Sieber M, Mettler D, Gänger H, Frey FJ. Marked interspecies differences between humans and pigs in cy- 
closporin and prednisolone disposition. Drug Metab Dispos 1988;16:285-9

9. Arneil GC. One hundred sixty four children with nephrosis. Lancet 1961;2:1103-10

10. Meyers S, Janowitz HD. Crohn's disease. Complications. In: Berk JE, ed. Bockus gastroenterology. Vol. 4. 4th ed. Philadelphia: W. B. Saunders, 1985:2294-305

11. Hoyumpa AM Jr, Schenker S. Hepatic encephalopathy. In: Berk JE, ed. Bockus gastroenterology. Vol. 5. 4th ed. Philadelphia: W. B. Saunders, 1985:3083-120

12. Eickhoff TC. Nosocomial infections. In: Hoeprich PD, ed. Infectious diseases. A modern treatise of infectious processes. 2nd ed. Hagerstown, Md: Harper \& Row, 1977: 27-33

13. Buchanan WW. Clinical features of rheumatoid arthritis. In: Scott JT, ed. Copeman's textbook of the rheumatic diseases. Sth ed. New York: Churchill Livingstone, 1978: 318-64

14. Stamm WE, Turck $M$. Urinary tract infection, pyelonephritis, and related conditions. In: Braunwald $E$, Isselbacher $\mathrm{KJ}$, Petersdorf RG, Wilson JD, Martin JB, Fauci AS, eds. Harrison's principles of internal medicine. Vol. 2. Ilth ed. New York: McGraw-Hill, 1987:1189-95

15. Hirschmann JV, Murray JF. Pneumonia and lung abscess. In: Braunwald E, Isselbacher KJ, Petersdorf RG, Wilson JD, Martin JB, Fauci AS, eds. Harrison's principles of internal medicine. Vol. 2. 11th ed. New York: McGrawHill, 1987:1075-82

16. Tramont EC. General or nonspecific host defense mechanisms. In: Mandell GL, Douglas RG Jr, Bennett JE, eds. Principles and practice of infectious diseases. 2nd ed. New York: John Wiley \& Sons, 1985:25-31

17. Sacks HS, Berrier J, Reitman D, Ancona-Berk VA, Chalmers TC. Meta-analyses of randomized controlled trials. N Engl J Med 1987;316:450-5

18. Thacker SB. Meta-analysis: a quantitative approach to research integration. JAMA 1988;259:1685-9

19. Bauer RB, Tellez H. Dexamethasone as treatment in cerebrovascular disease. 2. A controlled study in acute cerebral infarction. Stroke 1973;4:547-55

20. Beerel F, Jick H, Tyler JM. A controlled study of the effect of prednisone on air-flow obstruction in severe pulmonary emphysema. N Engl J Med 1963;268:226-30

21. Beerel FR, Vance JW. Prednisone treatment for stable pulmonary emphysema. Am Rev Respir Dis 1971;104:264-6

22. Bennett $A E$, Ingram GIC. A controlled trial of long-term steroid treatment in haemophilia. Lancet 1967;1:967-70

23. Binder A, Hazleman BL, Parr G, Roberts S. A controlled study of oral prednisolone in frozen shoulder. $\mathrm{Br} \mathrm{J}$ Rheumatol 1986;25:288-92

24. Black DAK, Rose G, Brewer DB. Controlled trial of prednisone in adult patients with the nephrotic syndrome. $\mathrm{Br}$ Med J 1970;3:421-6

25. Blair GP, Light RW. Treatment of chronic obstructive pulmonary disease with corticosteroids. Comparison of daily vs. alternate-day therapy. Chest 1984;86:524-8

26. Blitzer BL, Mutchnick MG, Joshi PH, Phillips MM, Fessel JM, Conn HO. Adrenocorticosteroid therapy in alcoholic hepatitis. A prospective, double-blind randomized study. American Journal of Digestive Disorders 1977;22;477-84

27. Blockey NJ, Wright JK, Kellgren JH. Oral cortisone ther- apy in periarthritis of the shoulder. A controlled trial. $\mathrm{Br}$ Med J 1954;1:1455-7

28. Braakman R, Schouten HJA, Blaauw-van Dishoeck M, Minderhoud JM. Megadose steroids in severe head injury. Results of a prospective double-blind clinical trial. J Neurosurg 1983;58:326-30

29. Campra JL, Hamlin EM, Kirshbaum RJ, Olivier M, Redeker AG, Reynolds TB. Prednisone therapy of acute alcoholic hepatitis. Report of a controlled trial. Ann Intern Med 1973;79:625-31

30. Chamberlain MA, Keenan J. The effect of low doses of prednisolone compared with placebo on function and on the hypothalamic pituitary adrenal axis in patients with rheumatod arthritis. Rheumatology and Rehabilitation 1976; 15:17-23

31. Christensen K, Jensen EM, Noer I. The reflex dystrophy syndrome response to treatment with systemic corticosteroids. Acta Chir Scand 1982;148:653-5

32. Clark S, Tindall E, Bennett RM. A double blind crossover trial of prednisone versus placebo in the treatment of fibrositis. J Rheumatol 1985;12:980-3

33. Collaborative study of the adult idiopathic nephrotic syndrome. A controlled study of short-term prednisone treatment in adults with membranous nephropathy. $\mathbf{N}$ Engl $\mathbf{J}$ Med 1979;301:1301-6

34. Cook GC, Mulligan R, Sherlock S. Controlled prospective trial of corticosteroid therapy in active chronic hepatitis. Q J Med 1971;40:159-85

35. Cooper PR, Moody S, Clark WK, Kirkpatrick J, Maravilla K, Gould AL, Drane W. Dexamethasone and severe head injury. A prospective double-blind study. J Neurosurg 1979;51:307-16

36. Copenhagen Study Group for Liver Diseases. Effect of prednisone on the survival of patients with cirrhosis of the liver. Lancet 1969;1:119-21

37. De Almeida M, Feneux D, Rigaud C, Jouannet P. Steroid therapy for male infertility associated with antisperm antibodies. Results of a small randomized clinical trial. Int J Androl 1985;8:111-7

38. Depew W, Boyer T, Omata M, Redeker A, Reynolds T. Double-blind controlled trial of prednisolone therapy in patients with severe acute alcoholic hepatitis and spontaneous encephalopathy. Gastroenterology 1980;78:524-9

39. Durelli L, Cocito D, Riccio A, Barile C, Bergamasco B, Baggio GF, Perla F, Deisidime M, Gusmaroli G, Bergamini L. High-dose intravenous methylprednisolone in the treatment of multiple sclerosis: clinical-immunologic correlations. Neurology 1986;36:238-43

40. Dyck PJ, O'Brien PC, Oviatt KF, Dinapoli RP, Daube JR, Bartleson JD, Mokri B, Swift T, Low PA, Windebank AJ. Prednisone improves chronic inflammatory demyelinating polyradiculoneuropathy more than no treatment. Ann Neurol 1982;11:136-41

41. Eaglstein WH, Katz R, Brown JA. The effects of early corticosteroid therapy on the skin eruption and pain of herpes zoster. JAMA 1970;211:1681-3

42. European Association for the Study of the Liver. Randomised trial of steroid therapy in acute liver failure. Gut 1979;20:620-3

43. Evans JA, Morrison IM, Saunders KB. A controlled trial of prednisone, in low dosage, in patients with chronic air- 
ways obstruction. Thorax 1974;29:401-6

44. Faupel G, Reulen HJ, Müller D, Schürmann K. Double-blind study on the effects of steroids on severe closed head injury. In: Pappius HM, Feindel W, eds. Dynamics of brain edema. New York: Springer Verlag, 1976;337-43

45. Goodman DH. Comparative study of cloprednol versus placebo in asthma. Ann Allergy 1978;40:376-80

46. Gregory PB, Knauer CM, Kempson RL, Miller R. Steroid therapy in severe viral hepatitis. A double-blind, randomized trial of methyl-prednisolone versus placebo. $\mathrm{N}$ Engl J Med 1976;294:681-7

47. Harris ED Jr, Emkey RD, Nichols JE, Newberg A. Lowdose prednisone therapy in rheumatoid arthritis: a double blind study. J Rheumatol 1983;10:713-2I

48. Hoofnagle JH, Davis GL, Pappas SC, Hanson RG, Peters M, Avigan MI, Waggoner JG, Jones EA, Seeff LB. A short course of prednisolone in chronic type B hepatitis. Report of a randomized, double-blind, placebo-controlled trial. Ann Intern Med 1986;104:12-7

49. Howard FM Jr, Duane DD, Lambert EH, Daube JR. Alternate-day prednisone: preliminary report of a doubleblind controlled study. Ann NY Acad Sci 1976;274:596-607

50. Helman RA, Temko MH, Nye SW, Fallon HJ. Alcoholic hepatitis. Natural history and evaluation of prednisolone therapy. Ann Intern Med 1971;74:311-21

51. Hughes RAC, Newsom-Davis JM, Perkin GD, Pierce JM. Controlled trial of prednisolone in acute polyneuropathy. Lancet 1978;2:750-3

52. James DG, Carstairs LS, Trowell J, Sharma OP. Treatment of sarcoidosis. Report of a controlled therapeutic trial. Lancet 1967;2:526-8

53. Koerner F, Merz A, Gloor B, Wagner E. Postoperative retinal fibrosis: a controlled clinical study of systemic steroid therapy. Graefes Arch Clin Exp Ophthalmol 1982;219: 268-71

54. Lam WK, So SY, Yu DYC. Response to oral corticosteroids in chronic airflow obstruction. Br $\mathrm{J}$ Dis Chest 1983;77:189-98

55. Lesesne HR, Bozymski EM, Fallon HJ. Treatment of alcoholic hepatitis with encephalopathy. Comparison of prednisolone with caloric supplements. Gastroenterology 1978:74:169-73

56. Maddrey WC, Boitnott JK, Bedine MS, Weber FL, Mezey E, White RI. Corticosteroid therapy of alcoholic hepatitis. Gastroenterology 1978;75:193-9

57. Malchow H, Ewe K, Brandes JW, Goebell H, Ehms H, Sommer H, Jesdinsky H. European cooperatve Crohn's disease study (ECCDS): results of drug treatment. Gastroenterology 1984;86:249-66

58. May M, Wette R, Hardin WB Jr, Sullivan J. The use of steroids in Bell's palsy: a prospective controlled study. Laryngoscope 1976;86:1111-22

59. McQueen EG. Betamethasone in stroke [letter]. N Z Med J 1978;87:103-4

60. Mendella LA, Manfreda J, Warren CPW, Anthonisen NR. Steroid response in stable chronic obstructive pulmonary disease. Ann Intern Med 1982;96:17-21

61. Mitchell DM, Gildeh P, Rehahn M, Dimond AH, Collins JV. Effects of prednisolone in chronic airflow limitation. Lancet 1984;2:193-5

62. Morgan WKC, Rusche E. A controlled trial of the effect of steroids in obstructive airway disease. Ann Intern Med 1964;61:248-54

63. Mulley G, Wilcox RG, Mitchell JRA. Dexamethasone in acute stroke. Br Med J 1978;2:994-6

64. Nair PV, Tong MJ, Stevenson D, Roskamp D, Boone C. Effects of short-term, high-dose prednisone treatment of patients with HBsA-positive chronic active hepatitis. Liver 1985;5:8-12

65. Norris JW. Steroid therapy in acute cerebral infarction. Arch Neurol 1976;33:69-71

66. Norris JW, Hachinski VC. High dose steroid treatment in cerebral infarction. Br Med J 1986;292:21-3

67. O'Reilly JFO, Shaylor JM, Fromings KM, Harrison BDW. The use of the 12 minute walking test in assessing the effect of oral steroid therapy in patients with chronic airways obstruction. Br J Dis Chest 1982;76:374-82

68. Patten BM, Mendell J, Bruun B, Curtin W, Carter S. Doubleblind study of the effects of dexamethasone on acute stroke. Neurology 1972;22:377-83

69. Powell-Tuck J, Bown RL, Chambers TJ, Lennard-Jones JE. A controlled trial of alternate day prednisolone as a maintenance treatment for ulcerative colitis in remission. Digestion 1981:22:263-70

70. Porter HP, Simon FR, Pope CE II, Volwiler W, Fenster LF. Corticosteroid therapy in severe alcoholic hepatitis. A double-blind drug trial. N Engl J Med 1971;284:1350-5

71. Prensky AL, Dodson WE. The steroid treatment of hereditary motor and sensory neuropathy. Neuropediatrics 1984; 15:203-7

72. Prout C, Dalrymple W. A double-blind study of eighty-two cases of infectious mononucleosis treated with corticosteroids. J Am Coll Heaith Assoc 1966;15:62-6

73. Rizza CR, Kernoff PBA, Matthews JM, McLennan CR, Rainsford SG. A comparison of coagulation factor replacement with and without prednisolone in the treatment of haematuria in haemophilia and Christmas disease. Thromb Haemost 1977;37:86-90

74. Schonfeld SA, Ploysongsang Y, Dilisio R, Crissman JD, Miller E, Hammerschmidt DE, Jacob HS. Fat embolism prophylaxis with corticosteroids. A prospective study in high-risk patients. Ann Intern Med 1983;99:438-43

75. Shim C, Stover DE, Williams MH Jr. Response to corticosteroids in chronic bronchitis. J Allergy Clin Immunol 1978;62:363-7

76. Shumaker JB, Resnick RH, Galambos JT, Makopour H, Iber FL. A controlled trial of 6-methylprednisolone in acute alcoholic hepatitis, with a note on published results in encephalopathic patients. Am J Gastroenterol 1978;69:443-9

77. Singleton JW, Law DH, Kelley ML Jr, Mekhjian HS, Sturdevant RAL. National Cooperative Crohn's Disease Study: adverse reactions to study drugs. Gastroenterology 1979; 77:870-82

78. Soloway RD, Summerskill WHJ, Baggenstoss AH, Geall MG, Gitnick GL, Elveback LR, Schoenfield LJ. Clinical, biochemical, and histological remission of severe chronic active liver disease: a controlled study of treatments and early prognosis. Gastronenterology 1972;63:820-33

79. Strain DS, Kinasewitz GT, Franco DP, George RB. Effect of steroid therapy on exercise performance in patients with irreversible chronic obstructive pulmonary disease. Chest 1985;88:718-21 
80. Summers RW, Switz DM, Sessions JT Jr, Becktel JM, Best WR, Kern F Jr, Singleton JW. National Cooperative Crohn's Disease Study: results of drug treatment. Gastroenterology 1979;77:847-69

81. Taverner D. Cortisone treatment of Bell's palsy. Lancet 1954;2:1052-4

82. Tellez H, Bauer RB. Dexamethasone as treatment in cerebrovascular disease. 1. A controlled study in intracerebral hemorrhage. Stroke 1973;4:541-6

83. Theodossi A, Eddleston ALWF, Williams R. Controlled trial of methylprednisolone therapy in severe acute alcoholic hepatitis. Gut 1982;23:75-9

84. Vakil BJ, lyer SN, Shah SC, Gadgil RK, Wagholikar UN. A controlled trial of prednisolone in the treatment of infective hepatitis. J Indian Med Assoc 1965;45:357-62

85. Ware AJ, Jones RE, Shorey JW, Combes B. A controlled trial of steroid therapy in massive hepatic necrosis. Am J Gastroenterol 1974;62:130-3

86. Ware AJ, Cuthbert JA, Shorey J, Gurian LE, Eigenbrodt EH, Combes B. A prospective trial of steroid therapy in severe viral hepatitis. The prognostic significance of bridging necrosis. Gastroenterology 1981;80:219-4

87. Wolf SM, Wagner JH Jr, Davidson S, Forsythe A. Treatment of Bell's palsy with prednisone: a prospective randomized study. Neurology 1978;28:158-61

88. Wilson WR, Byl FM, Laird N. The efficacy of steroids in the treatment of idiopathic sudden hearing loss. A doubleblind clinical study. Arch Otolaryngol 1980;106:772-6

89. Young RL, Harkleroad LE, Lordon RE, Weg JG. Pulmonary sarcoidosis: a prospective evaluation of glucocorticoid therapy. Ann Intern Med 1970;73:207-12

90. Haynes RC Jr, Murad F. Adrenocorticotropic hormone; adrenocortical steroids and their synthetic analogs: inhibitors of adrenocortical steroid biosynthesis. In: Gilman AG, Goodman LS, Rall TW, Murad F, eds. The pharmacological basis of therapeutics. 7th ed. New York: MacMillan Publishing, 1985;1459-89

91. Mantel N, Haenszel W. Statistical aspects of the analysis of data from retrospective studies of disease. JNCI 1959;22:719-48
92. Katz D, Baptista J, Azen SP, Pike MC. Obtaining confidence intervals for the risk ratio in cohort studies. Biometrics 1978;34:469-74

93. Armitage P. Statistical methods in medical research. Oxford: Blackwell Scientific Publications, 1971

94. Frey FJ. Kinetics and dynamics of prednisolone. Endocr Rev 1987;8(4):453-73

95. Bergrem $H$. The influence of uremia on pharmacokinetics and protein binding of prednisolone. Acta Med Scand 1983;213:333-8

96. Frey FJ, Schaad HJ, Renner EL, Horber FF, Frey BM, Preisig R. Liver function in stable renal transplant patients. Hepatology 1989;9(4):606-13

97. Frey BM, Frey FJ. The effect of altered prednisolone kinetics in patients with the nephrotic syndrome and in women taking oral contraceptive steroids on human mixed lymphocyte cultures. J Clin Endocrinol Metab 1985;60: 361-9

98. Renner E, Horber FF, Jost G, Frey BM, Frey FJ. Effect of liver function on the metabolism of prednisone and prednisolone in humans. Gastroenterology 1986;90:819-28

99. Zürcher RM, Frey BM, Frey FJ. Impact of ketoconazole on the metabolism of prednisolone. Clin Pharmacol Ther 1989;45:366-72

100. Stuck AE, Frey BM, Frey FJ. Kinetics of prednisolone and endogenous cortisol suppression in the elderly. Clin Pharmacol Ther 1988;43:354-62

101. Frey FJ, Frey BM. Urinary 6ß-hydroxyprednisolone excretion indicates enhanced prednisolone catabolism. J Lab Clin Med 1983;101:593-604

102. Frey BM, Frey FJ. Phenytoin modulates the pharmacokinetics of prednisolone and the pharmacodynamics of prednisolone as assessed by the inhibition of the mixed lymphocyte reaction in humans. Eur J Clin Invest 1984;14:1-6

103. Frey FJ, Horber FF, Frey BM. Altered metabolism and decreased efficacy of prednisolone and prednisone in hyperthyroid patients. Clin Pharmacol Ther 1989;44(5):510-21 